Brazilian Journal
of Chemical
Engineering

\title{
EXPANDED BED ADSORPTION OF BROMELAIN (E.C. 3.4.22.33) FROM Ananas comosus CRUDE EXTRACT
}

\author{
E. Silveira ${ }^{1}$, M. E. Souza-Jr' ${ }^{2}$ J. C. C. Santana ${ }^{1}$, A. C. Chaves $^{2}$, \\ A. L. F. Porto ${ }^{3}$ and E. B Tambourgi ${ }^{1 *}$ \\ ${ }^{1}$ School of Chemical Engineering, State University of Campinas, UNICAMP, \\ P. O. Box 6066, 13083-970, Campinas-SP, Brazil. \\ E-mail: eliastam@feq.unicamp.br \\ ${ }^{2}$ Laboratório de Biotecnologia, FFPNM/UPE, \\ ${ }^{3}$ Departamento de Morfologia e Fisiologia Animal, UFRPE; Fax: +(55) (19) 3521-3910.
}

(Submitted: August 14, 2007 ; Revised: May 8, 2008 ; Accepted: May 16, 2008)

\begin{abstract}
This work focuses on the adsorption of Bromelain in expanded bed conditions, such as the adsorption kinetics parameters. The adsorption kinetics parameters showed that after 40 minutes equilibrium was achieved and maximum adsorption capacity was $6.11 \mathrm{U}$ per resin $\mathrm{mL}$. However, the maximum adsorption capacity was only determined by measuring the adsorption isotherm. Only by the Langmuir model the maximum adsorption capacity, Qm, and dissociation constant, $\mathrm{kd}$, values could be estimated as $9.18 \mathrm{U} / \mathrm{mL}$ and 0.591 , respectively, at $25{ }^{\circ} \mathrm{C}$ and $0.1 \mathrm{~mol} / \mathrm{L}$ phosphate buffer $\mathrm{pH} 7.5$. A column made of glass with an inner diameter of $1 \mathrm{~cm}$ was used for the expanded bed adsorption (EBA). The residence time was reduced 10 fold by increasing the expansion degree 2.5 times; nonetheless, the plate number $(\mathrm{N})$ value was reduced only 2 fold. After adsorption, the bromelain was eluted in packed bed mode, with a downward flow. The purification factor was about 13 fold and the total protein was reduced 4 fold. EBA showed to be feasible for purification of bromelain.

Keywords: Adsorption; Enzyme Activity; Purification; Axial Dispersion; Expanded Bed Adsorption; Bromelain.
\end{abstract}

\section{INTRODUCTION}

The pineapple (Ananas comosus L.) is cultivated extensively in Hawaii, Philippines, Caribe, Malaysia, Australia, Mexico, South Africa and Brazil. Brazil is the pineapple's second worldwide producer with 45,000 planted hectares. The main planted areas are the rain forest and northeast, although it is cultivated all around the country (Silveira, 2007).

The stem and fruit bromelains (formerly E.C. 3.4.22.4 and E.C. 3.4.22.5, respectively) are extracted from the $A$. comosus. Considered by many to be a whole fruit, it is in fact an infrutescence. Many independent fruits are bonded together in one body around a fibrous stem. The stem bromelain (E.C. 3.4.22.32) is the most abundant endopeptidase cystein in the pineapple's stem. It exhibits a broad specificity for protein cleavage, having a strong preference for Z-Arg-Arg-|-NHMec amongst the small molecule substrates (Hatano, et al., 1998; Harrach et al., 1998; Hatano et al., 2002; Haq et al., 2002; Rasheedi, 2003; Khan et al., 2003; Gaspani et al., 2002). The fruit bromelain (E.C. 3.4.22.33) is extracted from the pineapple infrutescence. It hydrolyzes proteins with a broad specificity for peptide bonds. Bz-Phe-Val-Arg-|-NHMec is a good synthetic substrate, but there is no action on Z-ArgArg-|-NHMec (Maurer, 2001).

*To whom correspondence should be addressed 
Expanded Bed Adsorption (EBA) is a chromatographic technique for separation and purification of biological products directly from crude feedstock, without centrifugation, microfiltration and other prior clarification steps (Chase, 1994; Hjorth; 1997; Thömmes, 1997; Anspach et al., 1999; Trinh et al., 2006; Camprubi et al., 2006; Tan et al., 2006). This technique permits crude feeding into the chromatographic column without initial treatment and, as the bed expands, it increases adsorbent surface contact, making interaction with the target molecule more effective (Roy et al., 1999; Fernandez-Lahore et al., 2001).

Several works on expanded bed adsorption have contributed to a better understanding of the effects of adsorption, emphasizing studies of adsorbent type and size (Yamamoto et al., 2001; Dainiak et al., 2002), bed height, linear velocity (Mullick and Flickinger, 1999), fluidization and elution solution effects on residence time distribution (FernandezLahore et al., 2001; Santos et al., 2000; Santos et al., 2002) for application in the recovery of important biomolecules.

The axial dispersion in EBA is a parameter of greater importance, as it reveals the flow performance, the adsorption and mass transfer mechanisms of biomolecules and the particular adsorption behaviors along the bed. Non-uniform axial distribution of particle size and local bed voidage are always established within the bed, due to broad size and/or particle density, which results in the variation of the axial dispersion with the bed height (Bruce and Chase, 2001; Yun et al., 2004a; Yun et al., 2004b).

In the present work, bromelain from a crude extract of Ananas comosus was purified by expanded bed adsorption with Amberlite IRA 410 ionexchange resin on a glass column $(1 \mathrm{~cm}$ i.d.). The effect of expansion degree of resin bed on bromelain purification was studied and also a residence time distribution study was performed.

\section{MATERIAL AND METHODS}

\section{Reagents}

Amberlite IRA 410 ion-exchange resin was purchased from VETEC (São Paulo, Brazil). Pineapple, Ananas comosus cv. Smooth cayenne, was purchased at a local market. All others reagents were of analytical grade.

\section{EBA Column}

A glass column of $1 \mathrm{~cm}$ inner diameter and $40 \mathrm{~cm}$ height with an adjustable piston on the top, feed inlet at the bottom and an outlet at the top was used. A sixty mesh plate at the feed inlet was used to avoid loss of adsorbent particles. A ruler was placed along the column to measure the bed height.

\section{Enzyme Extract}

The enzyme extract was obtained from the pineapple's (A. comosus) infrutescence. The pineapple's stem and fruit were processed in a blender and then filtered in a sixty mesh filter to remove the plant tissue fibres.

\section{Enzyme Assay}

The bromelain proteolytic activity was estimated by the method described by Kunitz (1973) and modified by Walter (1984), using casein $2 \%(\mathrm{w} / \mathrm{v})$ as substrate and tyrosine as standard. One enzymatic unit was defined as the bromelain amount necessary to produce $1 \mu \mathrm{mol} / \mathrm{mL}$ of tyrosine in 1 minute at $37^{\circ} \mathrm{C}$.

\section{Protein Determination}

The total protein concentration was determined by the method described by Deutscher (1990) using albumin as standard. The protein concentration was measured by absorbance at $280 \mathrm{~nm}$.

\section{Adsorption Equilibrium and Kinetics}

In kinetic experiments, $2 \mathrm{~mL}$ of drained resin was mixed up with $20 \mathrm{~mL}$ of buffered bromelain solutions $(0.1 \mathrm{~mol} / \mathrm{L}$ phosphate buffer $\mathrm{pH} 7.5)$. The adsorption was carried out in a shaking incubator at $25^{\circ} \mathrm{C}$. At different time intervals, supernatant samples of $0.5 \mathrm{~mL}$ were analysed for bromelain activity. Using this procedure, the time course of bromelain activity decrease was determined.

In adsorption equilibrium experiments, $5 \mathrm{~mL}$ of drained resin was added to $25 \mathrm{~mL}$ of bromelain extract solutions of different concentrations. The aqueous solution was $0.1 \mathrm{~mol} / \mathrm{L}$ phosphate buffer $(\mathrm{pH} 7.5)$. Adsorption experiments were conducted at $25^{\circ} \mathrm{C}$ for $2 \mathrm{~h}$ in a shaking incubator $(100 \mathrm{rpm})$. At the end of adsorption, the solid phase was separated and the supernatant was analyzed for bromelain activity. The activity of adsorbed bromelain was calculated by mass balance. 


\section{Determination of Bed Voidage $(\varepsilon)$}

Bed voidage was obtained by substitution of data for specific mass $\left(\rho_{\mathrm{p}}\right)$ and mass of the adsorbent particles $\left(\mathrm{m}_{\mathrm{P}}\right)$, cross sectional area of the column $\left(\mathrm{A}_{\mathrm{T}}\right)$ and bed height $(\mathrm{H})$ into the following equation (Santos et al., 2000; Fernandez-Lahore et al., 2001; Yamamoto et al., 2001):

$$
\varepsilon=1-\frac{V_{\mathrm{P}}}{V_{B}}=1-\frac{V_{P}}{A_{T} H}=1-\frac{m_{P}}{\rho_{\mathrm{P}} A_{T} H}
$$

where $V_{P}$ is the particle volume and $V_{B}$ is the bed volume.

\section{Residence Time Distribution (RTD) Study}

Phosphate buffer at $0.1 \mathrm{~mol} / \mathrm{L}$ concentration and at $\mathrm{pH} 7.5$ was used as fluidizer; the bed was fluidized until the bed height achieved the pre-determined height (1.5, 2.0 and 2.5 times the initial bed height). All experiments were carried out at standard conditions of temperature and pressure $\left(25^{\circ} \mathrm{C}\right.$ and 1 $\mathrm{atm})$. An acetone solution $(2.5 \% \mathrm{v} / \mathrm{v})$ was used as tracer. The acetone solution was fed into the column until a maximum UV signal was observed at the outlet and then, the feed solution was switched to buffer and samples collected at the column outlet at time intervals varying with the flow velocity.

The RTD curves were obtained by the negative pulse method. Figure 1 shows how RTD curves were determined experimentally. The mean residence time $(\mathrm{t})$ and the standard deviation $(\sigma)$ were substituted into equation (2) to obtain the number of theoretical plates $(\mathrm{N})$.

$$
N=\frac{t^{2}}{\sigma^{2}}
$$

Axial dispersion $\left(\mathrm{D}_{\text {axial }}\right)$ was calculated as described in equation (3)

$$
\mathrm{HETP}=\frac{\mathrm{UH}}{2 \varepsilon \mathrm{D}_{\text {axial }}}
$$

where $\mathrm{U}$ is the flow velocity.

\section{Bromelain Purification}

Expanded bed adsorption was carried out at $25^{\circ} \mathrm{C}$, 1 atm and $\mathrm{pH}$ 7.5. The adsorbent bed was preequilibrated at the desired height, with $0.1 \mathrm{~mol} / \mathrm{L}$ phosphate buffer at $\mathrm{pH} 7.5$. A $4.0 \mathrm{~cm}$ bed height was expanded to $6.0,8.0$, and $10 \mathrm{~cm}$; these bed heights correspond to $1.5,2.0$ and 2.5-fold expansion degrees, respectively. $25 \mathrm{~mL}$ of enzyme solution, $1.02 \mathrm{U} / \mathrm{mL}$ of enzyme and $2.7 \mathrm{mg} / \mathrm{mL}$ of protein, in phosphate buffer at $\mathrm{pH} 7.5$, were loaded onto the column bottom for adsorption of bromelain on Amberlite IRA 410 ion-exchange resin. After adsorption, the column was washed until the protein concentration at the outlet reached the baseline. The elution was performed with a continuous $0.1-0.5$ $\mathrm{mol} / \mathrm{L} \mathrm{NaCl}$ gradient at $0.95 \mathrm{~mL} / \mathrm{min}$ in downward flow. The bromelain activity and protein concentration were measured from time to time during adsorption, washing and elution periods.

\section{SDS-PAGE}

SDS-PAGE was performed according to the method described by Hochstrasser et al. (1998a; 1998 b) for silver staining. The molar mass range was from $24 \mathrm{kDa}$ to $66 \mathrm{kDa}$, and the markers were Trypsinogen (24 kDa); Carbonic Anhydrase (29 $\mathrm{kDa}$; Glyceraldehyde-3-phosphate dehydrogenase $(36 \mathrm{kDa})$; Ovoalbumin (45 kDa); Glutamic dehydrogenase (55 kDa); and Albumin (66 kDa).

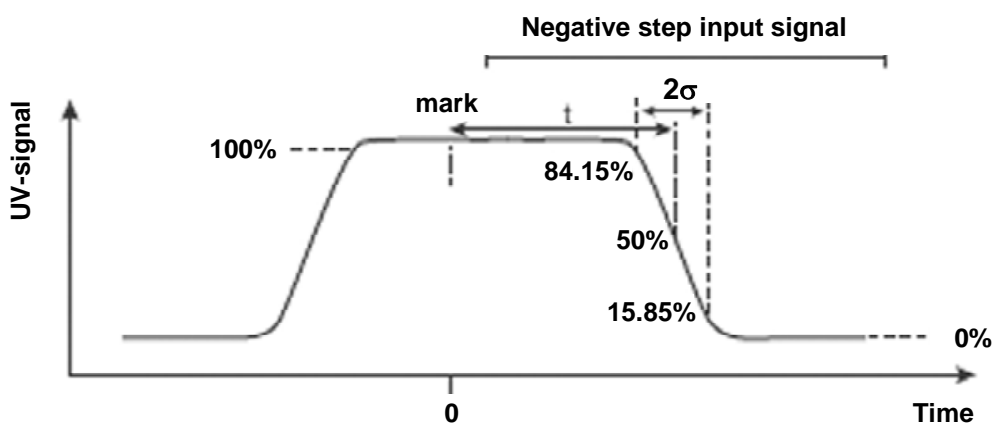

Figure 1: Scheme of UV-signal record at the bed outlet during RTD test 


\section{RESULTS AND DISCUSSION}

\section{Characterization of Amberlite IRA 410}

Figure 2 shows the adsorption isotherms of bromelain on Amberlite IRA 410 ion-exchange adsorbent. The adsorption isotherm was well expressed by the Langmuir equation:

$$
\mathrm{Q}=\mathrm{Q}_{\mathrm{m}} \frac{\mathrm{c}}{\mathrm{k}_{\mathrm{d}}+\mathrm{c}}
$$

The adsorption of bromelain was near $6.11 \mathrm{U} / \mathrm{mL}$ of resin at $25^{\circ} \mathrm{C}$ and $0.1 \mathrm{~mol} / \mathrm{L}$ phosphate buffer $\mathrm{pH}$ 7.5 , although the maximum adsorption capacity $\left(\mathrm{Q}_{\mathrm{m}}\right)$ was nearly $9.2 \mathrm{U} / \mathrm{mL}$ of resin. The dissociation constant $\left(\mathrm{k}_{\mathrm{d}}\right)$ was $0.591 \mathrm{U} / \mathrm{mL}$. The main difficulty in obtaining kinetic constants from bromelain adsorption was the limited amount of enzyme per $\mathrm{cm}^{3}$ of vegetative tissue. In addition, the Ananas comosus stem is very fibrous, requiring the addition of distilled water during the extraction of the enzyme, diluting the extract.

Lali et al. (1989) claimed that the wall effect on the bed expansion behaviour is negligible as long as the ratio of column to particle diameter is larger than 20 . Because the value of this ratio in this work was larger than 20, the bed expansion experiments should be influenced by the wall effect. The bed expansion degrees for the resin are shown in Figure 3, and the expansion degrees for Streamline are also shown for comparison.

Amberlite IRA 410 has a specific mass $\left(\rho_{\mathrm{p}}\right)$ of $1.12 \mathrm{~g} / \mathrm{mL}$ and a particle diameter of $4 \times 10^{-4} \mathrm{~m}$. Although the specific mass is smaller than streamline material (Amersham Pharmacia, 1997), the particle diameter is greater, resulting in lower expansion degrees with higher flow velocities, as shown in Figure 3.

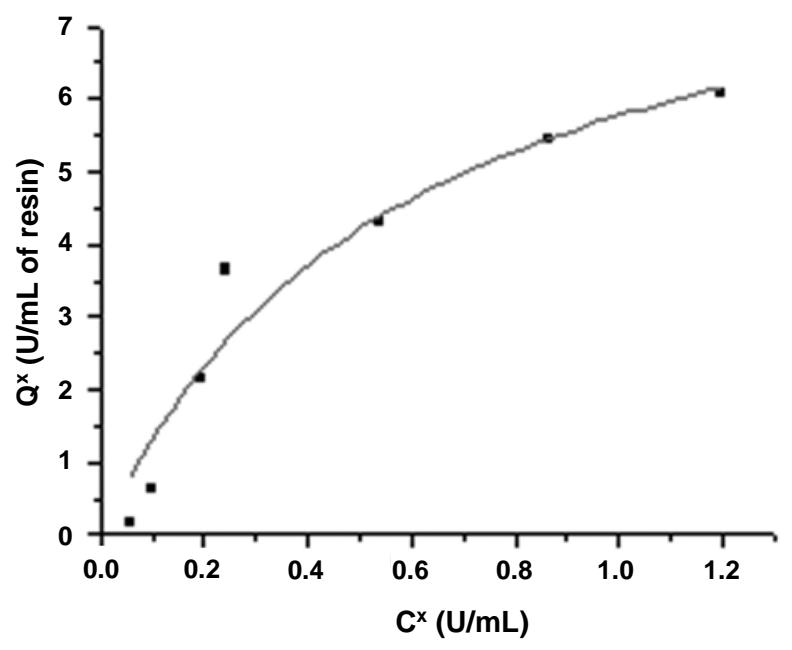

Figure 2: Adsorption equilibrium curve based on bromelain activity at $25{ }^{\circ} \mathrm{C}$

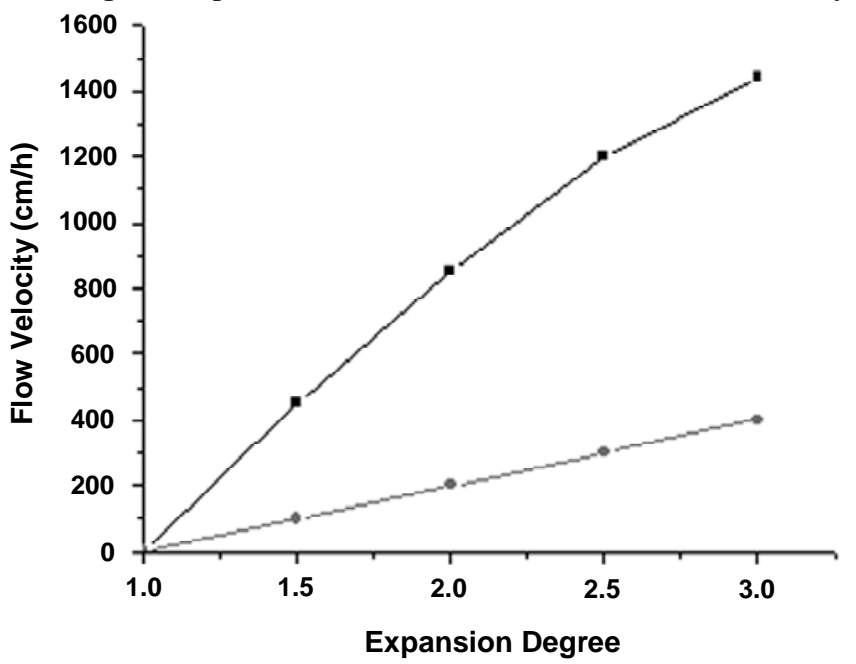

Figure 3: Expansion degree of $(\bullet)$ Streamline resin and (•) Amberlite IRA 410 ion-exchange resin 


\section{Residence Time Distribution Study}

Figure 4 shows RTD curves for acetone $(2.5 \%$ $\mathrm{w} / \mathrm{v})$ tracer as it passed through the column bed. Analyzing the RTD obtained after a perfect iontracer pulse (axial dispersion, plug-flow exchange of mass with stagnant zones) gave a quantitative description of the underlying hydrodynamic situation during the EBA process (Fernandez-Lahore et al., 2001).

Table 1 shows the RTD results after substitution of data into equations (1) to (3), according to the methodology used by several authors (Santos et al., 2000; Fernandez-Lahore et al., 2001; Yamamoto et al., 2001; Toledo et al., 2006).

As detailed in Table 1, the liquid axial dispersion increased with bed height and hence with expansion degree. There was a 12-fold increase in axial dispersion when the expansion degree was raised 1.5 fold and a 51-fold increase as its expansion degree increased 2.5 fold. This increase in axial dispersion facilitates the flow of particles and biological material into the bed and increases the interaction of target molecule and adsorbent particles, facilitating the feed of crude extract directly to the bed, avoiding fouling and reducing costs, as the number of pretreatment and pre-purification steps may be reduced, which are the main chromatographic problems (Wheelwright, 1994; Amersham Pharmacia, 1997; Fernandez-Lahore et al., 2001).

\section{Expanded Bed Adsorption of Bromelain}

Table 2 shows the results for Bromelain by expanded bed adsorption on Amberlite IRA 410. The recovery yield increased as the expansion degree increased, which should occur because there are more adsorbent-target molecule interactions in expanded beds than in fixed beds, by the increase of the influence of bed voidage. This effect was also reported by Chang et al. (1994), and Santos (2000) working with G6PDH and lysozyme, respectively.

As the expanded bed lengthened, there was also an increase in the specific activity. This shows that bromelain purification is somehow proportional to the expansion degree or flow velocities under the conditions studied here. Similar results were found by Toledo et al. (2006) working with $\alpha$-amylase. It also agrees with the RTD study, because the bed height increases the contact between enzymes and the ion-exchange resin, Amberlite IRA 410.

The purification factor also rose as the expanded bed height increased. The purification factor of the expanded bed at 2.5 -fold expansion degree increased more than 12-fold, which is higher than in reverse micellar systems (Hebbar et al., 2008) or aqueous two-phase systems (Rabelo et al., 2004). This purification factor was close to those reported in ionexchange chromatography for several enzymes (Kim et al., 2000; Wang et al., 2008). However, the use of DEAE-cellulose and DEAE-sephacel resins increased the cost of purification of biomolecules. With the use of Amberlite IRA 410 ion-exchange resin and the expanded bed condition, it was possible to obtain pure biological products, such as bromelain, with lower operational cost, thus, decreasing overall process cost (Fernandez-Lahore et al., 2001).

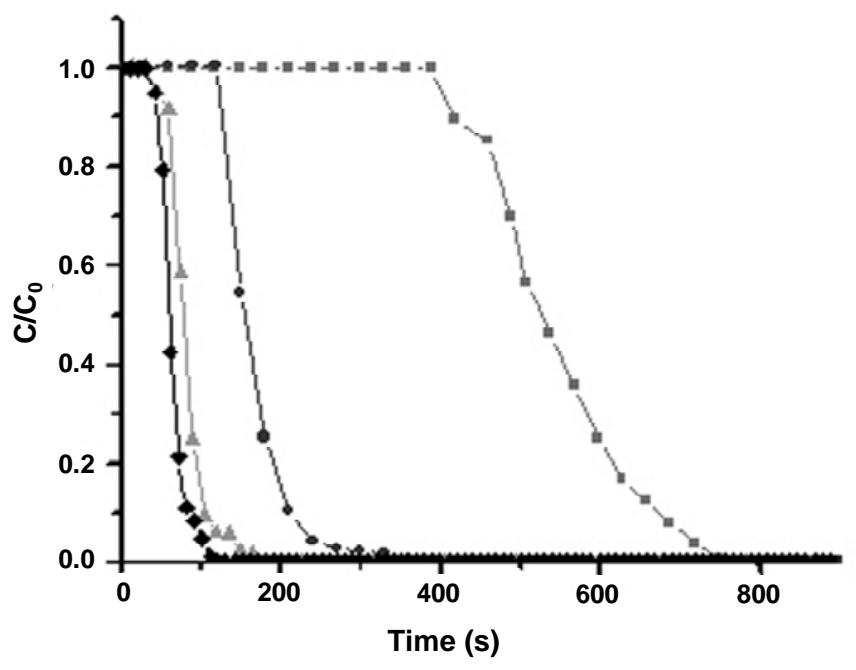

Figure 4: RTD tests using acetone as tracer. $(\boldsymbol{\square}) \mathrm{H}=4.0 \mathrm{~cm}$;

(•) $\mathrm{H}=6.0 \mathrm{~cm} ;(\boldsymbol{\Delta}) \mathrm{H}=8.0 \mathrm{~cm} ;(\bullet) \mathrm{H}=10 \mathrm{~cm}$ 
Table 1: Experimental stability parameters obtained by RTD tests using acetone as tracer

\begin{tabular}{|c|c|c|c|c|c|c|}
\hline Bed & $\mathbf{H}(\mathbf{c m})$ & $\mathbf{N}$ & HETP $\left.\mathbf{( 1 0}^{-3}\right)$ & $\varepsilon$ & $\mathbf{U}(\mathbf{c m} / \mathbf{h})$ & $\mathbf{D}_{\text {axial }}\left(\mathbf{c m}^{2} / \mathbf{s}\right)$ \\
\hline Fixed & 4.0 & 37.09 & 1.08 & 0.440 & 72.61 & 0.089 \\
\hline \multirow{3}{*}{ Expanded } & 6.0 & 20.21 & 2.97 & 0.627 & 454.39 & 1.076 \\
& 8.0 & 19.68 & 4.06 & 0.720 & 850.7 & 2.401 \\
& 10.0 & 16.89 & 5.92 & 0.776 & 1200 & 4.578 \\
\hline
\end{tabular}

Table 2: Expanded bed height influence on Bromelain recovery by EBA

\begin{tabular}{|c|c|c|c|c|c|}
\hline Samples & H (cm) & Activity (U/mL) & Protein (mg/mL) & S.A. (U/mg) & P.F. \\
\hline Crude & n/a & 1.02 & 2.7 & 0.379 & 1 \\
\hline & 4.0 & 0.088 & 0.104 & 0.851 & 2.24 \\
Recovered & 6.0 & 0.146 & 0.080 & 1.829 & 4.82 \\
& 8.0 & 0.263 & 0.081 & 3.214 & 8.48 \\
& 10.0 & 0.330 & 0.071 & 4.641 & 12.24 \\
\hline
\end{tabular}

S.A. $=$ specific activity; P.F. $=$ Purification Factor

The protein and bromelain activity history is presented in Figure 5. It shows that bromelain was eluted in a single peak, although there was an overlap of the first and second peak. This might have occurred due to variations in buffer composition at the column outlet; the stepwise gradient provides at least three different buffer compositions travelling through the column at the same time. This might have caused the overlap to appear in the chromatogram, which showed more than one protein peak, although it is related to a difference in the mobile-phase composition, not to the heterogeneity of the product (Wheelwright, 1994) as seen in the SDS-PAGE of the collected extract (Figure 6).

The SDS-PAGE analysis shows that the eluted peaks containing bromelain activity were electrophoretically pure. The estimated molecular weight of bromelain was around $32.2 \mathrm{kDa}$; similar results were found by Silverstein and Kezdy (1975), $35 \mathrm{kDa}$; and Murachi (1976), $33 \mathrm{kDa}$. However, Ota et al. (1972), Takahashi et al. (1973), Wharton (1974), and Suh et al. (1992) have found different molecular weights for bromelain, $28 \mathrm{kDa}, 28 \mathrm{kDa}$, $28.4 \mathrm{kDa}$, and $37 \mathrm{kDa}$, respectively.

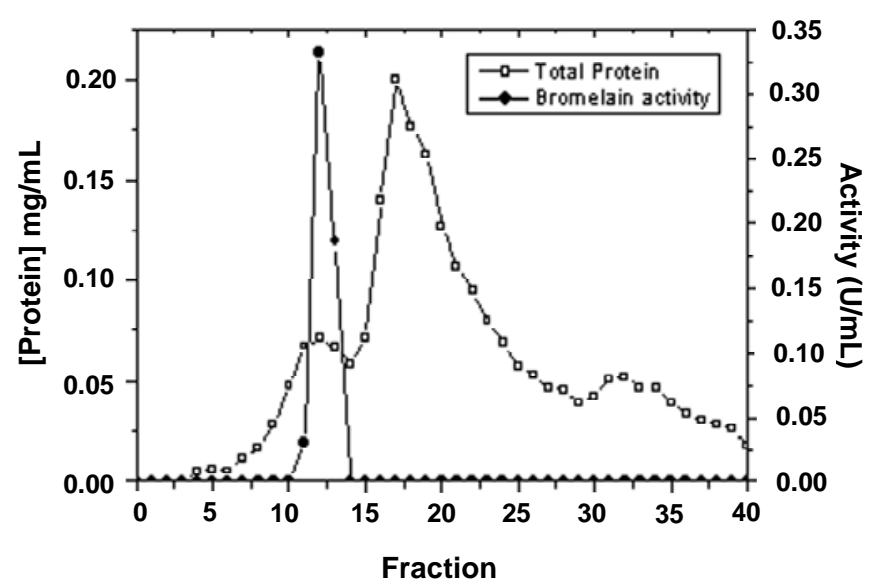

Figure 5: The protein and bromelain activity history for fractions collected during the elution step in fixed bed mode. 


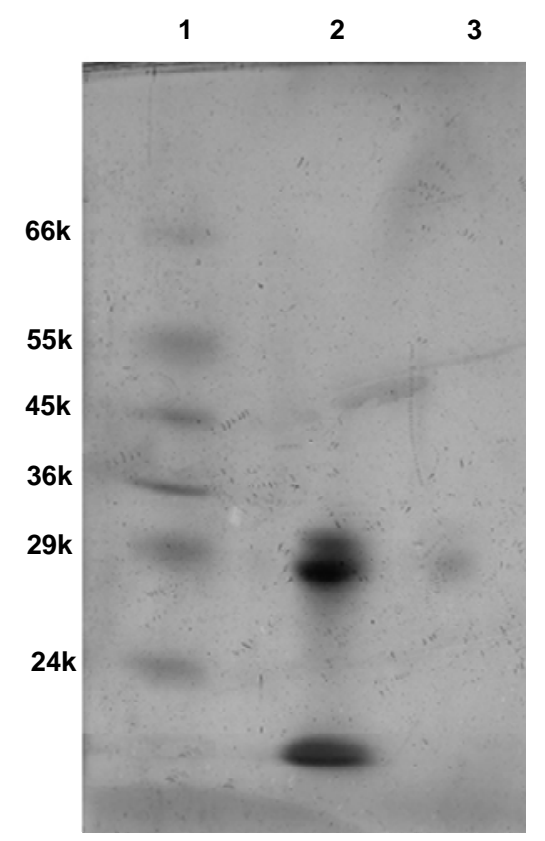

Figure 6: SDS-PAGE. Lane 1 - molecular weight markers; Lane 2 - Crude Extract; Lane 3 - Eluted bromelain extract by the EBA at $\mathrm{H}=10 \mathrm{~cm}$. The molecular markers are Trypsinogen $(24 \mathrm{kDa})$; Carbonic Anhydrase (29 kDa); Glyceraldehyde-3-phosphate dehydrogenase (36 kDa); Ovoalbumin (45 kDa); Glutamic dehydrogenase $(55 \mathrm{kDa})$; and Albumin $(66 \mathrm{kDa})$

\section{CONCLUSIONS}

This work showed that the purification of bromelain by expanded bed adsorption is feasible by using Amberlite IRA 410 as adsorbent, showing good activity for the recovered extract and a good purification factor for the purification process as well. It was also shown that, by increasing flow velocity, other variables also increase such as bed expansion, bed voidage, HEPT and axial dispersion, which lead to a high purification factor and an electrophoretically pure product.

\section{ACKNOWLEDGEMENT}

The authors acknowledge the aid of Monique Ferraz and Igor Teixera with the SDS-PAGE technique. The authors are also thankful to Capes and $\mathrm{CNPq}$ for financial support.

\section{REFERENCES}

Amersham Pharmacia Biotech. EBA Handbook: Principles and Methods. Uppsala, ISBN 91-6305519-8 (1997).
Anspach, F. B., Curbelo, D., Hartman, R., Garke, G., Deckwer, W. D., Expanded-bed chromatography in primary protein purification, J. Chromatogr. A. 865:129 (1999).

Bruce, L. J., Chase, H. A., Hydrodynamics and adsorption behaviour within an expanded bed adsorption column studied using in-bed sampling, Chem. Eng. Sci. 56:3149 (2001).

Camprubi, S., Bruguera, M., Canalias, F., Purification of recombinant histidine-tag streptolysin $\mathrm{O}$ using immobilized metal affinity expanded bed adsorption (IMA-EBA). International J. Biol. Macromolecules. 38: 134139 (2006).

Chang, Y.,K., McCreath, G.E., Chase, H.,A., in: Galindo, E.; Ramirez, O.T. (Eds.). Advances in Bioprocess Engineering, Kluwer Academics Publisher: Netherlands, p. 519 (1994).

Chase, H. A., Purification of proteins by adsorption chromatography in expanded beds, Trends Biotechnol. 12:296 (1994).

Dainiak, M. B., Galaev, I. Y., Matiasson, B., Direct capture of product from fermentation broth using a cell-repelling ion exchanger. J. Chromatogr. A, 942:123-131 (2002).

Deutscher, M. P., Guide to protein purification. Method. Enzymol. p. 182 (1990). 
Fernandez-Lahore, H. M., Lin, D-Q., Hubbuch, J. J., Kula, M. R., Thommes, J., The use of ionselective electrodes for evaluating residence time distributions in expanded bed adsorption systems. Biotechnol. Progr. 17:1128-1136 (2001).

Gaspani, L., Limiroli, E., Ferrario, P., Bianchi, M., In vivo and in vitro effects of bromelain on PGE(2) and SP concentrations in the inflammatory exudate in rats. Pharmacology 65:83-86 (2002).

Haq, S. K., Rasheedi, S., Khan, R. H., Characterization of a partially folded intermediate of stem bromelain at low $\mathrm{pH}$. Eur. J. Biochem. 269:47-52 (2002).

Harrach, T., Eckert, K., Maurer, H. R., Machleidt, I., Machleidt, W., Nuck, R., Isolation and characterization of two forms of an acidic bromelain stem proteinase. J. Protein Chem. 17:351-361 (1998).

Hatano, K., Sawano, Y., Tanokura, M., Structurefunction relationship of bromelain isoinhibitors from pineapple stem. Biol. Chem. 383:1151-1156 (2002).

Hatano, K., Tanokura, M., Takahashi, K., The amino acid sequences of isoforms of the bromelain inhibitor from pineapple stem. J. Biochem. 124:457-461 (1998).

Hjorth, R., Expanded bed adsorption in industrial bioprocessing: recent developments, Trends Biotechnol. 15:230 (1997).

Hochstrasser, D. F., Patchornik, A., and Merril, C. R., Development of polyacrylamide gels that improve the separation of proteins and their detection by silver staining. Analyt. Biochem. 173:412-423 (1998a).

Hochstrasser, D. F. and Merril, C. R., 'Catalysts' for polyacrylamide gel polymerization and detection of proteins by silver staining. Appl. Theor. Electrophoresis 1:35-40 (1998b).

Hebbar, H. U., Sumana, B., Raghavarao, K. S. M. S., Use of reverse micellar systems for the extraction and purification of bromelain term from pineapple wastes. Bioresource Technology 99: 4896-4902 (2008).

Khan, R. H., Rasheedi, S., Haq, S. K. Effect of pH, temperature and alcohols on the stability of glycosylated and deglycosylated stem bromelain. J. Biosci. 28:709-714 (2003).

Kim, M. H., Kim, H. K., Lee, J. K., Park, S. Y., Oh, T. K., Thermostable lipase of Bacillus stearothermophilus, high level production, purification and calciumdependent thermostability. Korea Res. Inst. Biosci. Biotechnol. 64:280-286 (2000).
Kordel, M., Hofmann, B., Schomburg, D., Schimid, R. D., Extracelluar lipase of Pseudomonas sp. strain ATCC 21808: purification, characterization, crystallization and preliminary X-ray diffraction data. J. Bacteriol. 173:4836-4841 (1991).

Kunitz, M., Crystalline soybean trypsin inhibitor: II general properties. J. Gen. Physiol. 30:291-310 (1974).

Lali, A. M., Khare, A. S., Joshi, J. B., Behaviour of solid particles in viscous non-newtonian solutions: Settling velocity, wall effects and bed expansion in solid-liquid fluidized beds. Powder Tech. 57:39-50 (1989).

Maurer, H. R., Bromelain: biochemistry, pharmacology and medical use. Cell. Mol. Life Sci. 58:1234-1245 (2001).

Mullick, A., Flickinger, M. C., Expanded bed adsorption of human serum albumin from very dense saccharomyces cerevesiae suspensions on fluoride-modified zirconia. Biotechnol. Bioeng. 65:282-290 (1999).

Murachi, T., Bromelain enzymes. Methods Enzymol. 45:475-485 (1976).

Ota, S., Horie, K., Hagino, F., Hashimoto, C., Date, H., Fractionation and some properties of the proteolytically active components of bromelains in the stem and the fruit of the pineapple plant. J. Biochem. 71:817-830 (1972).

Rasheedi, S., Haq, S. K., Khan, R. H., Guanidine hydrochloride denaturation of glycosylated and deglycosylated stem bromelain. Biochemistry 68:1097-1100 (2003).

Roy, I., Pai, A., Lali, A., Gupta, M. N., Comparison of batch, packed bed and expanded bed purification of $A$. niger cellulose beads. Bioseparation. 8:317-326 (1999).

Santos, E. S., Guirardello, R., Franco, T. T., Distributor Effect on Expanded Bed Adsorption. In: International Conference IEX 2000 (Ion Exchange at the Millennium), Cambridge/UK (2000).

Santos, E. S., Guirardello, R., Franco, T. T., Preparative chromatography of xylanase using expanded bed adsorption. J. Chrom. A. 944: 217224 (2002).

Silveira, E., Purificação e caracterização de bromelina a partir do extrato bruto de Ananas comosus por adsorção em leito expandido. Dissertação de Mestrado. Faculdade de Engenharia Química: Unicamp (2007).

Silverstein, R. M., Kezdy, F. J., Characterization of the pineapple stem proteases (bromelain). Arch. Biochem.Biophys. 167:678-686 (1975). 
Suh, H. J., Lee, H., Cho, H. Y., Yang, H. C., Purification and characterization of bromelain isolated from pineapple. Han'guk Nonghwa Hakhoechi 35:300-307 (1992).

Takahashi, N., Yasuda, Y., Goto, K., Miyake, T., Murachi, T., Multiple molecular forms of stem bromelain. Isolation and characterization of two closely related components, SB1 and SB2. J. Biochem. 74:355-373 (1973).

Tan, Y. P., Ling, T. C., Tan, W. S., Yusoff, K., Tey, B. T., Purification of recombinant nucleocapsid protein of Newcastle disease virus from unclarified feedstock using expanded bed adsorption chromatography. Prot. Expr. Purif. 46: 114-121 (2006).

Thömmes, J., Fluidized bed adsorption as a primary recovery step in protein purification, Adv. Biochem. Eng. 58:185 (1997).

Toledo, A. L., Severo, J. J. B., Souza, R. R., Campos, E. S., Santana, J. C .C., Tambourgi, E. B., Purification by expanded bed adsorption and characterization of an a-amylase FORILASE NTL ${ }^{\circledR}$ from A. niger, J. Chrom. B, 846:51-56 (2006).

Trinh, L., Phue, J-N., Jaluria, P., Tsai, C. W., Narum, D. L., Shiloach, J., Screen-less expanded bed column: new approach for the recovery and purification of a malaria transmission blocking vaccine candidate from Pichia pastoris. Biotechnol. Lett. 28: 951-958 (2006).

Walter, H. E., Proteinases: methods with hemoglobin, casein, and azocoll as substrates. Pp. 270-277 in Methods of Enzymatic Analysis, Vol. 5, H.U. Bergmeyer, ed. Verlag Chemie, Weinheim, Germany (1984).

Wang, S.-L., Peng, J.-H., Liang, T.-W., Liu, K.-C., Purification and characterization of a chitosanase from Serratia marcescens TKU011. Carbohydrate Research. 343: 1316-1323 (2008).

Wharton, C. W., The structure and mechanism of stem bromelain. Evaluation of the homogeneity of purified stem bromelain, determination of the molecular weight and kinetic analysis of the bromelain-catalysed hydrolysis of $\mathrm{N}$ benzyloxycarbonyl-L-phenylalanyl-L-serine methyl ester. Biochem. J. 143:575-586 (1974).

Wheelwright, S. M., Protein purification: design and scale up of downstream processing. Munich: Hanser Publishers (1994).

Yamamoto, S., Okamoto, A., Walter, P., Effects of adsorbent properties on zone spreading in expanded bed chromatography. Bioseparation, 1:1-10 (2001).

Yun, J. X., Yao, S.-J., Lin, D.-Q., Lu, M.-H., Zhao, W.-T., Modeling axial distributions of adsorbent particle size and local voidage in expanded bed, Chem. Eng. Sci. 59:449 (2004a).

Yun, X.J., Lin, D.-Q., Lu, M.-H., Zhong, L.-N., Yao, S.-J., Measurement and modeling of axial distribution of adsorbent particles in expanded bed: taking into account the particle density difference, Chem. Eng. Sci. 59:5873 (2004b). 